\title{
A Bayesian Chronology for Early Domestic Horse Use in the Eastern Steppe
}

William Timothy Treal Taylor ${ }^{1^{*}}$, Jargalan Burentogtokh ${ }^{2}$, K. Bryce Lowry ${ }^{3}$, Julia Clark ${ }^{4}$, Tumurbaatar Tuvshinjargal $^{5}$, and Jamsranjav Bayarsaikhan ${ }^{6}$

${ }^{1}$ Max Planck Institute for the Science of Human History, 10 Kahlaische Strasse, Jena, Germany 07745

${ }^{2}$ Yale University

${ }^{3}$ University of Chicago

${ }^{4}$ American Center for Mongolian Studies

${ }^{5}$ National Museum of Mongolia

*corresponding author

Keywords: horse domestication, pastoralism, Bayesian modeling

\begin{abstract}
Archaeological horse remains from Mongolia's late Bronze Age Deer Stone-Khirigsuur (DSK) culture present some of the oldest direct radiocarbon dates for horses in northeast Asia, hinting at an important link between late Bronze Age social developments and the adoption or innovation of horse transport in the region. However, wide error ranges and imprecision associated with calibrated radiocarbon dates obscure the chronology of early domestic horse use in Mongolia and make it difficult to evaluate the role of processes like environmental change, economic interactions, or technological development in the formation of mobile pastoral societies. Using a large sample of new and published radiocarbon dates, this study presents a Bayesian chronological model for the initiation of domestic horse sacrifice at DSK culture sites in Mongolia. Results reveal the rapid spread of horse ritual over a large portion of the eastern Steppe circa 1200 BCE, concurrent with the first appearance of draught horses in China during the late Shang dynasty. These results suggest that key late Bronze Age cultural transformations specifically the adoption of mobile pastoralism and early horseback riding - took place during a period of climate amelioration, and may be linked to the expansion of horses into other areas of East Asia.

Introduction
\end{abstract}

Researchers studying eastern Eurasia have considered a wide range of potential processes to explain the formation of mobile pastoral groups in the region. Models prioritizing the causative role of sedentary agricultural societies have greatly influenced academic discourse (e.g. Chang and Koster 1986:105; Lattimore 1940:58-61; Lees and Bates 1974). However, recent years several detailed regional studies indicate that across most of the eastern Eurasian steppe, hunting and gathering directly preceded the first herding groups, with little influence from sedentary states (e.g. Clark 2014:26; Frachetti 2008:20-21; Janz 2012:185; Wright 2006:285). Other influential models for nomadic origins 
prioritize the negative pressures of climate deterioration or resource scarcity (Kradin 2003:75). For example, Khazanov (1984:93) linked the development of highly mobile nomadic societies in eastern Eurasia with a prolonged period of drought and climate deterioration - which he argues would have prompted herders to seek new ways to subsist in a more challenging environment. The innovation or adoption of horseback riding has also been connected with the emergence of migratory herding societies in eastern Eurasia during the late Bronze and early Iron Age (e.g. Beardsley 1953). However, as these different social, technological and environmental processes took place at different times and scales in prehistoric Eurasia, assessing the relationship between horseback riding, incipient mobile pastoralism, and other hypothesized causes requires a precise and reliable chronological framework for domestic horse use.

\section{The horse in pastoral societies}

Horses provide critical subsistence advantages in arid and cold environments that may have made them particularly valuable to early pastoral groups in eastern Eurasia. From their initial domestication in western Central Asia ca. 3500 BCE, horses also provided meat, milk and secondary products (Olsen 2006; Outram et al. 2009) that may have been essential to the success of pastoral peoples, providing important vitamins and nutrients that are rare in other domestic livestock (Levine 1998:94). Horses can subsist on lower quality forage than other ruminants (Mitchell 2015:43-44), and are able to use their hooves to access winter pastures that have been frozen or crusted over, improving herd survival for copastured livestock (Anthony and Brown 2011). For these reasons, some have suggested that domestic horses were essential to the development of Inner Asian pastoralism during the late Holocene (Levine 1998).

Beyond their function as a basic livestock animal, horses also had key implications for nomadic life as a form of transport. Although the movement of any given herd is limited in some respects by the speed of its slowest animal, horseback riders can move 2-3 times as far per day as those moving on foot alone (Anthony et al. 1991). The increased efficiency of movement provided by mounted riding more than doubles the number of sheep that can be effectively controlled by a single herder working with dogs (Anthony and Brown 2006:149). Improved travel speed would have enabled pastoralists to tend larger herds at farther distances from camp, much as it did among reindeer herders of northern Finland following the introduction of the snowmobile (Müller-Wille and Pelto 1971). In the Eastern steppe, where rain is highly seasonal and pastures are easily overgrazed, the added efficiency of movement and herd control might have dramatically expanded the scale of viable herding activities. Consequently, characterizing the chronology horse transport is fundamental to an understanding of pastoral herding in eastern Eurasia.

\section{Horse use and early pastoralism in Mongolia}

While the specific chronology of pastoralism in Mongolia remains ambiguous, a variety of archaeological evidence indicates that mobile herding groups flourished in the region during the late Bronze Age. In some areas of Mongolia, people practiced mixed hunting, agriculture, and perhaps domestic livestock breeding as far back as the Neolithic (Allard and Erdenebaatar 2005:547-8; Honeychurch 2015:110). Burials containing possibly domestic livestock and linked with a pastoral economy, such as those of the Afanasievo and Chemurchek cultures, have been found in some regions 
of Mongolia as early as the third millennium BCE (Eregzen 2016:18-49; Janz et al. 2017:54-56; Kovalev and Erdenebaatar 2010), suggesting that pastoral lifeways in the region could have great antiquity.

Nonetheless, a variety of important social transformations related to mobile herding appear to have occurred towards the end of the second millennium BCE (Allard and Erdenebaatar 2005:548; Honeychurch 2015:110). At this time, large kurgan-like mounds known as khirigsuurs, sometimes accompanied by anthropomorphic deer stones - tall standing stones decorated with weapons, tools, and often elaborate deer images were first constructed across the steppes of Mongolia, southern Tuva, eastern Kazakhstan, and northern Xinjiang (Bayarsaikhan 2016; Fitzhugh 2009:185; Volkov 1981 [2002]). Together, these two types of monument are referred to as the Deer Stone-Khirigsuur (DSK) Complex (Fitzhugh 2009). Faunal remains from a handful of late Bronze Age campsites indicate that DSK people had a dietary reliance on domestic sheep, goat, and cattle (Clark 2014; Houle 2010), and settlement studies suggest that DSK people built only ephemeral residential structures (Allard et al. 2007; Houle 2010).

Small stone ritual structures surrounding deer stones and khirigsuurs, hereafter referred to as 'satellite' features, yield important insights into how animals were used in DSK society. At many DSK sites, stone circles containing charcoal and calcined bone fragments of sheep/goat and cattle are found around the monument perimeter, and attest to ritual burning and consumption of livestock like sheep/goat and cattle (Broderick et al. 2014). Significantly, inhumations of horse skulls, hooves, and neck bones, oriented to face east, are also found around the perimeter of DSK sites (Allard and Erdenebaatar 2005; Fitzhugh 2009). Skeletal remains from these partial horse burials provide insights into how the animals were used. Characteristic osteological changes to the skull indicate that many of these horses were bridled and heavily exerted, while demographic data from dentition suggest that adult male animals were buried in prominent ritual locations (Taylor et al. 2015; Taylor 2016). Together, these data suggest an increasingly important role for horses in DSK society, concurrent with the adoption of mobile herding lifeways.

By at least the second millennium BCE, horse-drawn vehicles were employed in the western Central Asian steppes, likely by semi-nomadic, agropastoral people who may have practiced seasonal migrations (Khazanov 1984:93-94). Such vehicles may also have played an important role in Bronze Age life in Mongolia, as evidenced by a large corpus of petroglyphs showing 'chariots' (horses pulling wheeled vehicles) found on Mongolian rock art panels, and variously attributed to the $3^{\text {rd }}$ through the $1^{\text {st }}$ millennium BCE (Erdene-Ochir and Khodyakov 2016: 23-30). By ca. 1200 BCE, horses and light horse carts reached central China, appearing in oracle bone records and elite burials at the site of Yinxu in Henan province (Kelekna 2009).

Other archaeological data demonstrate the emergence of mounted horseback riding during the late Bronze Age, prior to most estimates for the end of the DSK period (ca. 700 BCE, Fitzhugh 2009a). Horse tack convincingly linked to mounted riding was interred in the kurgan of Arzhan I, dating to ca. 800 BCE, and similar finds from sites of the "slab burial" culture in Mongolia (Honeychurch et al. 2009: 347). These dates also correspond closely to the first historical mentions of mounted warriors in classical histories from western Eurasia (Argent 2011:31). If, as some suggest, nomadic peoples were among the first to adopt mounted riding (Mair 2003:181), the emergence of horsemanship in East Asia must have 
occurred in the preceding decades or centuries - concurrent with the construction of deer stones and khirigsuurs.

\section{DSK horse use in chronological context}

Due to challenges with monument dating and aggregation, however, the exact relationships between the DSK complex, changes in horse transport, and processes of social or environmental change are difficult to distinguish. Although horse burials can be found in mounds surrounding both deer stones and khirigsuurs, the earliest deer stones appear to postdate the earliest khirigsuurs by at least a century (Fitzhugh 2009a:189; Honeychurch 2015:117). Consequently, viable estimates for incipient horse use in DSK culture may fall across a relatively wide interval, between ca. 1500-1200 BCE (e.g. Fitzhugh 2009a; Honeychurch 2015:112-121). The precise timing of DSK horse use within this interval has critical implications for the role of environmental change in early mobile pastoralism. For example, one influential hypothesis links the development of East Asian mobile herding societies with a prolonged period of drought during the second millennium BCE (Khazanov 1984). Some recent paleoclimate research appears to corroborate the existence of such an event on northern Mongolian plateau (Feng et al. 2013; Propokenko et al. 2007; Wang et al. 2011), but the wide range of estimates for DSK cultural activity make it impossible to assess the impacts of this drought on DSK lifeways with any accuracy.

Improved chronological precision is also necessary to evaluate links between late Bronze Age horse use in Mongolia and the broader Eurasian region. For example, some researchers have hypothesized that DSK sites may have greater antiquity in northern Mongolia than elsewhere in the eastern steppes (Clark 2014:72; Fitzhugh 2009b:402). If valid, this might reflect a gradual diffusion of horses into the region out of southern Siberia and Kazakhstan circa 1400 BCE, before reaching China during the $12^{\text {th }}$ century BCE (Honeychurch 2015:121). Thus, clarifying the implications of DSK horse ritual for the spread of horses into East Asia, as well as the ecological and environmental context of early pastoralism in the region, requires overcoming issues of poor temporal resolution.

\section{Bayesian analysis of radiocarbon dates in archaeology}

Bayesian statistical techniques offer a potential solution to chronological imprecision in archaeological contexts. After calibration, radiocarbon date ranges often span several centuries and produce irregular probability distributions, complicating fine-grained temporal analysis (Dee et al. 2013). Another important source of analytical error arises during the interpretation of multiple dates, as the wide calibrated error ranges with statistical scatter inclines researchers to overestimate the chronological range represented by a given group of measurements (Bayliss 2009:130). Bayesian radiocarbon modeling, which uses prior archaeological information to model the probability distribution of unknown parameters such as the start or end of a cultural phase (Bronk Ramsey 2009; Bronk Ramsey and Lee 2013). The technique produces a modeled posterior probability distribution that provides a more precise estimate of archaeological phenomena, and if done correctly, a more reliable means of interpreting aggregate radiocarbon dates (Bronk Ramsey 1998). Because the resulting distribution is a reflection of both data and prior assumptions, an inappropriate prior can greatly influence the accuracy of the data (Steier and Rom 2000). However, because of the huge uncertainty ranges involved in calibrated radiocarbon dates, archaeological chronologies can still be markedly improved by using a 
relatively 'uninformative' prior - one that imposes very little bias on the resulting probability estimates (Bayliss 2015:132). Here, we present several models using uninformative or weakly informative priors to estimate the onset of cultural activity at deer stones and khirigsuurs and interpret results in light of extant hypotheses for the origins of mobile pastoralism and horse transport in eastern Eurasia.

\section{Materials and Methods}

Aggregating published ${ }^{14} \mathrm{C}$ dates

To estimate the timing of DSK horse use, we compiled new and published radiocarbon dates on horse remains from late Bronze Age archaeological sites. We surveyed Mongolian and English language academic publications for direct dates on archaeological horse bones from deer stones or khirigsuurs. Taxonomic identifications were generally not provided in analyzed literature for published radiocarbon dates from charcoal specimens (Table S1). However, we excluded measurements or samples of equivocal association to DSK monuments, including bone or charcoal specimens that did not originate from within a closed feature context (such as the central mound of a khirigsuur or from within a stone circle or mound surrounding a DSK monument). We also omitted those published dates which did not report original uncalibrated measurements. In total, we identified 44 published dates on horse bone or tooth specimens from stone burial features located at deer stones and khirigsuurs across Mongolia (Table S1).

New ${ }^{14}$ C analysis

We collected new archaeological horse material from 14 DSK horse features at localities in underrepresented regions, including Uvs, Zavkhan, Bulgan, and Bayankhongor provinces, to correct for oversampling in other areas of Mongolia (especially Khuvsgul province in northern Mongolia). For each of our bone and tooth samples, we surface cleaned and rinsed each specimen for one hour in an ultrasonic water bath. We then removed exterior and cancellous portions of the sample with a sterilized drill bit, before crushing and sieving to produce a $500 \mathrm{mg}$ sample with uniform particle size $(0.5-1 \mathrm{~mm}$ diameter). The bone powder was then loaded into a flow cell (a modified chromatography column) and, using a computer controlled pumping system, demineralized using $0.5 \mathrm{M}$ hydrochloric acid, extracted with $0.1 \mathrm{M}$ sodium hydroxide $(\mathrm{NaOH})$ to remove humic and fulvic acids, and then rinsed with weak acid $(0.001 \mathrm{M} \mathrm{HCl})$. After ensuring each sample had a final $\mathrm{pH}$ of 3 , the insoluble collagen fraction was removed from the flow cell and gelatinized by heating to $70^{\circ} \mathrm{C}$ for 20 hours. Each gelatinized sample was cooled to room temperature, filtered through a $0.45 \mu \mathrm{m}$ glass microfiber filter with polypropylene housing, and then lyophilized. Carbon isotope stable ratios of the samples were measured by the Accelerator Mass Spectrometry laboratory at the University of Arizona, Tucson, AZ.

\section{Modeling DSK horse use}

Using the resulting sample of 59 uncalibrated dates on DSK horse remains (Table S1), we produced a single-phase Bayesian model with a uniform prior using the program OXCAL and the INTCAL13 radiocarbon calibration curve (Bronk Ramsey and Lee 2013). To identify potential spatio- 
temporal gradients in horse use, we produced 'time slice' maps showing modeled posterior probabilities for each calibrated date, using GPS coordinates from published field reports or personal correspondence from the original investigator. We repeated this analysis once with an 'outlier model' which identifies and down-weighs anomalous measurements (Bronk Ramsey 2009:356). To accommodate the possibility that a uniform prior does not adequately characterize the likelihood of sampling horse remains from the DSK period, we also ran the model using a trapezoid prior (Lee and Bronk Ramsey et al. 2012). This approach allows for greater sampling likelihood towards the center of the phase (i.e. 'battleship curve'), a feature that is often more characteristic of archaeological phenomena than a uniform probability across time. All models ran successfully until completion (see Appendix I for OxCal code used in the analysis).

\section{Modeling deer stone and khirigsuur construction}

To assess the relationship between early domestic horse use and late Bronze Age cultural developments, we also modeled construction of non-horse features at deer stones and khirigsuurs, using 46 radiocarbon estimates, included 44 previously published values and two new dates analyzed as part of this study. These included 9 dates from charcoal excavated from within stone circles or mounds at deer stones, 30 dates on human bone from inside khirigsuurs, one date on charcoal from a khirigsuur satellite feature, and five dates on sheep or unspecified animal remains from deer stone and khirigsuur satellite features (Table S1).

Detailed taphonomic study suggests that although many khirigsuurs were disturbed in antiquity, many contain human remains (Littleton et al. 2012). It must be noted that non-mortuary functions have also been proposed for khirigsuurs, and others do not contain recognizable traces of human burials (Wright 2012:148). Nonetheless, radiocarbon dates on human remains recovered from within the central khirigsuur mound can be reasonably assumed to date the time of feature construction. Linking dates from ritual features surrounding DSK monuments to the event of construction is more problematic. Some researchers have suggested that individual sacrifice mounds accumulated around monuments over a prolonged period of time (Allard and Erdenebaatar 2005:558; Wright 2014:154), while others consider organized layouts (Houle 2017:160-161) or small samples of similar radiocarbon dates between some individual satellite mounds as evidence of a single dedication ceremony (Fitzhugh and Bayarsaikhan 2009:219; Fitzhugh 2017:23).

Whether or not these ritual features were built during a single ceremony or accumulated over time, each sample from a given feature produces a reliable estimate of construction for at least that single structure. Therefore, these data can be used in aggregate to characterize the chronology of ritual activities at deer stones and khirigsuurs. Moreover, ritual features at deer stones seem to produce dates more reliably connected with DSK cultural activity than other alternatives, such as organic material recovered near the stone base (Fitzhugh 2004:14-17). However, it should be noted that as the vast majority of dated human remains in our sample come from Khuvsgul province in northern Mongolia, this khirigsuur sample may not effectively characterize the timing of DSK monument construction across the broader Mongolian region. Using the modeled posterior probabilities, we tested the hypothesis that 
'start' boundaries for each type of monument (deer stones and khirigsuurs) preceded the 'start' boundary for DSK horse ritual using OxCal's Order function.

\section{Results}

Estimates for the start of horse ritual at deer stones and khirigsuurs across all models place the onset of domestic horse burial practices at DSK sites at ca. 1200 BCE. Our trapezoid model produced a boundary estimate of 1260-1124 cal. BCE (95\% probability) or 1226-1156 cal. BCE (68\% probability), with a median value of 1191 cal. BCE (Figure 1). The substitution of a uniform prior resulted in a similar but earlier boundary midpoint estimate of $1265-1150$ cal. BCE (95\% probability) or 1235-1176 cal. BCE (68\% probability). Because the algorithm used by OxCal allows the 'tails' of the trapezoid distribution to vary according to the distribution of the data, the similarity of these two modeled start boundaries implies that the uniform prior assumption of a rapid phase transition was robust (Lee and Ramsey 2012:121). Although a few samples yielded agreement indices below the arbitrary threshold of $60 \%$, the application of an outlier model did not significantly alter boundary estimates. Trapezoid model estimates for the termination of DSK horse ritual place this boundary between 803 and 685 cal. BCE.

Estimated trapezoid phase start dates drawn from human remains, non-horse livestock, and charcoal from deer stones and khirigsuurs raise the possibility that, by the time horses were incorporated into DSK ritual activity, khirigsuurs had been constructed in Mongolia for a century or more (start boundary estimate of 1443-1350 cal. BCE, 68\% probability, Figure 2). In contrast, the estimated start boundary for deer stone construction derived from non-horse material does not differ significantly from the horse start boundary estimate (1292-1146 cal. BCE, $68 \%$ probability). A test of the relative ordering of these three start boundaries using the 'Order' function in OxCal confirms these interpretations (Table 1), indicating a high probability that khirigsuur construction preceded the first deer stones (95.35\%) as well as the first construction of horse ritual features (99.99\%). On the other hand, the Order function does not provide strong evidence to differentiate the first deer stone construction from horse ritual (65.16\%).

Spatial pattern analysis indicates that very soon after its initial adoption, horse ritual was practiced over a wide geographic expanse of the Mongolian steppe. Figure 3 shows time slice maps of all horse remains with associated GPS or geographic location information. In this figure, the diameter of each circle reflects the relative percentage of the modeled posterior probability for each date - such that for each analyzed sample, the corresponding circle diameter is widest in its most probable timeslice. The map shows that by $1200 \mathrm{BCE}$, horse ritual was practiced across much of the territory of modern Mongolia, with many data points at or approaching their widest diameter (Figure 3A, right). Importantly, this process does not seem to have had a recognizable spatial gradient, with some of the earliest dates occurring on samples from Dundgovi province in southeastern Mongolia, Bayankhongor province in central Mongolia, and the Darkhad basin along the Siberian border. The youngest dates on deer stone horses appear to have persisted in the northern reaches of the country until ca. $750 \mathrm{BCE}$ (Figure 3, C-E). 

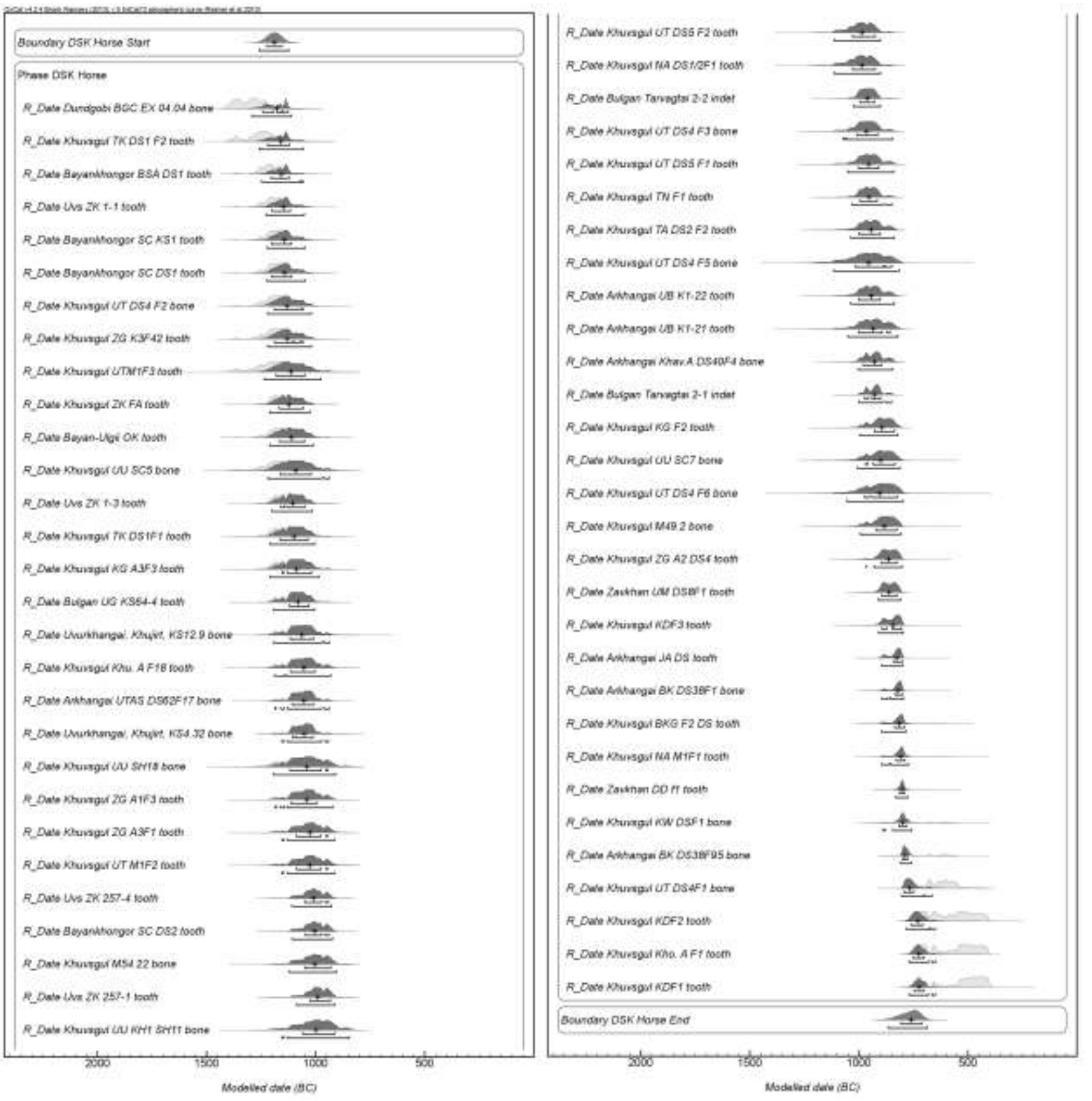

Figure 1. Posterior calibrated probability ranges for $14 \mathrm{C}$ dates from horse remains at deer stones and khirigsuurs. Prior distribution indicated in light gray, with median estimated indicated by $(+)$ and one and two-sigma probability ranges shown below. Distributions labeled "DSK Horse Start" and "DSK Horse End" summarize the estimated start and end boundary for horse ritual at DSK sites. 


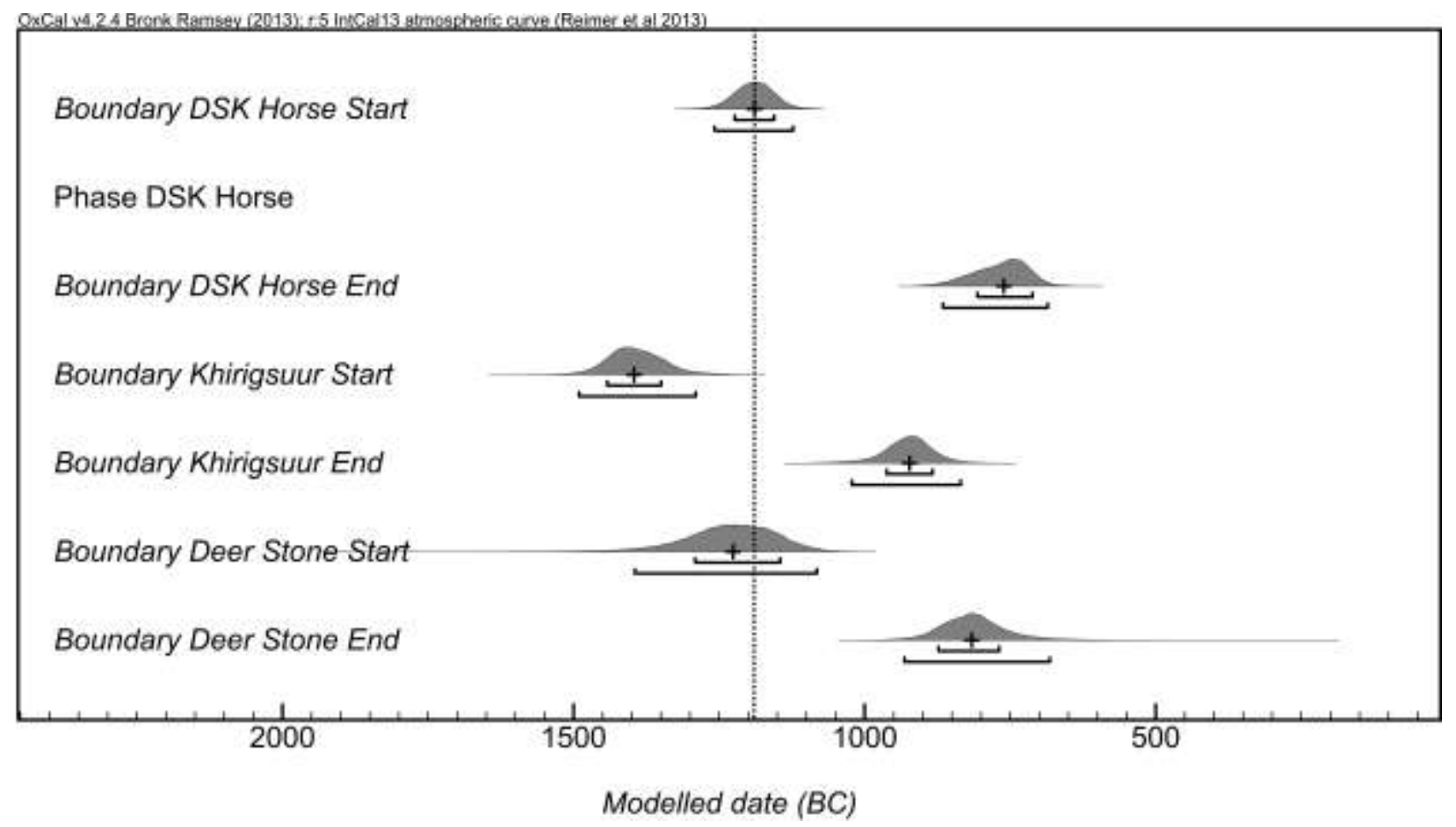

Figure 2. Modeled start and end dates for DSK horses, Khirigsuurs, and deer stones. Dashed line indicates median modeled start date for DSK horse ritual, falling within the 1-sigma range for deer stones but outside the modeled probability distribution for khirigsuurs.

Table 1. Probability that t1 (left column) precedes t2 (top row) using OXCAL's Order function.

\begin{tabular}{|c|c|c|c|}
\hline & \multicolumn{3}{|c|}{ Event 2} \\
\hline & DS & KS & Horse \\
\hline DS & --- & $4.654 \%$ & $65.16 \%$ \\
\hline KS & $95.35 \%$ & --- & $99.99 \%$ \\
\hline Horse & $34.84 \%$ & $0.001 \%$ & --- \\
\hline
\end{tabular}



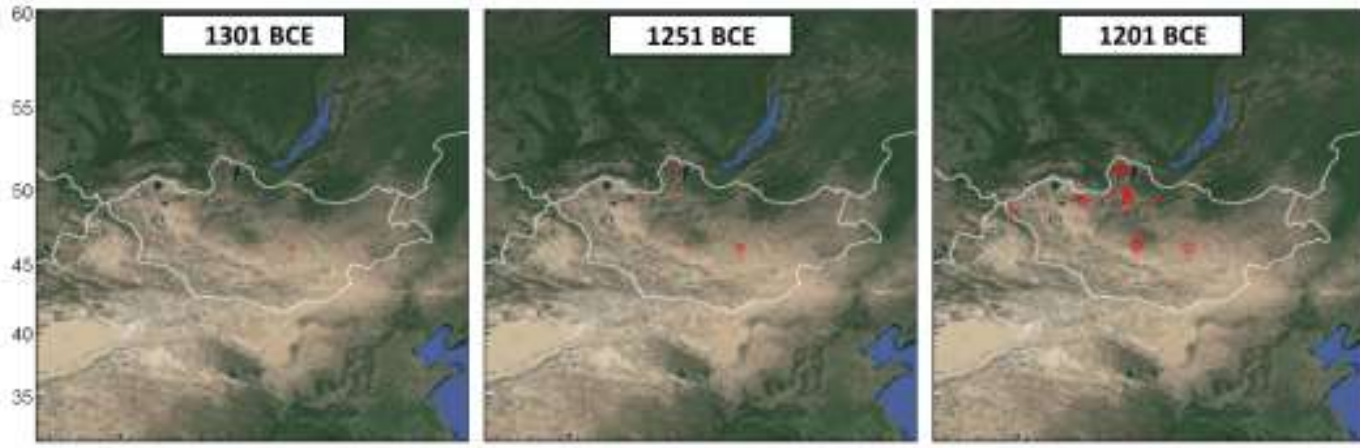

A
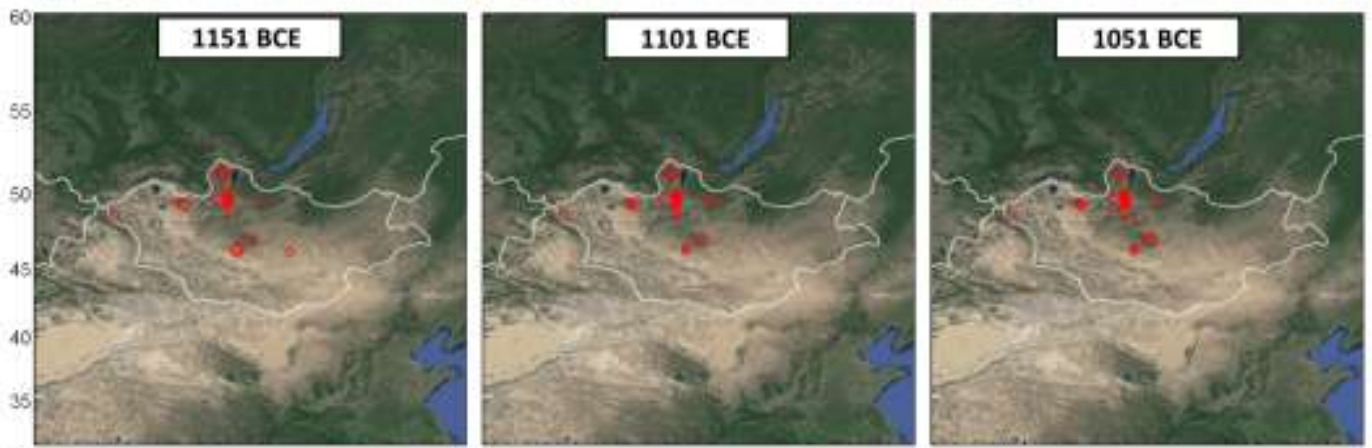

B
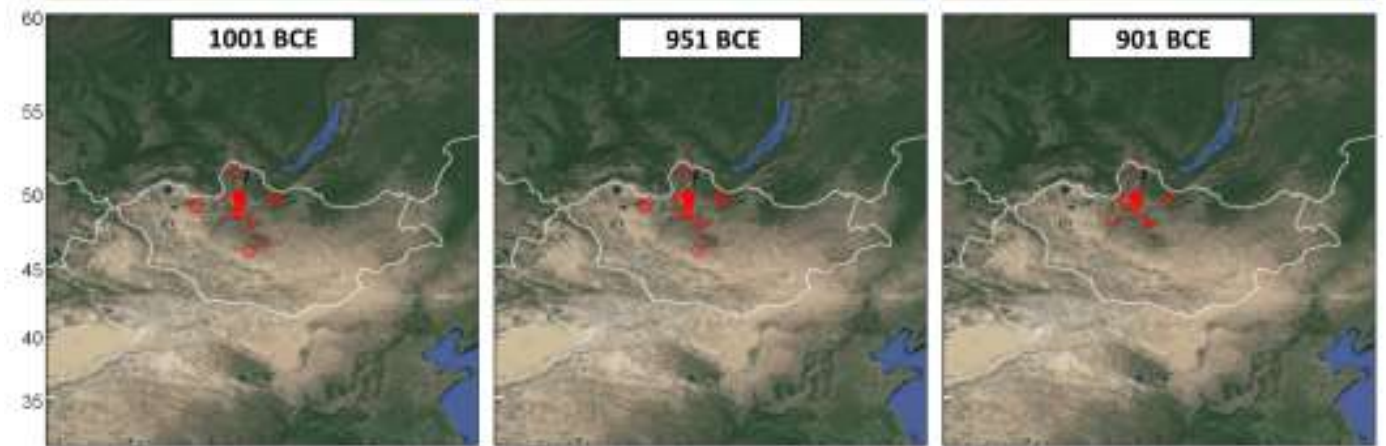

C
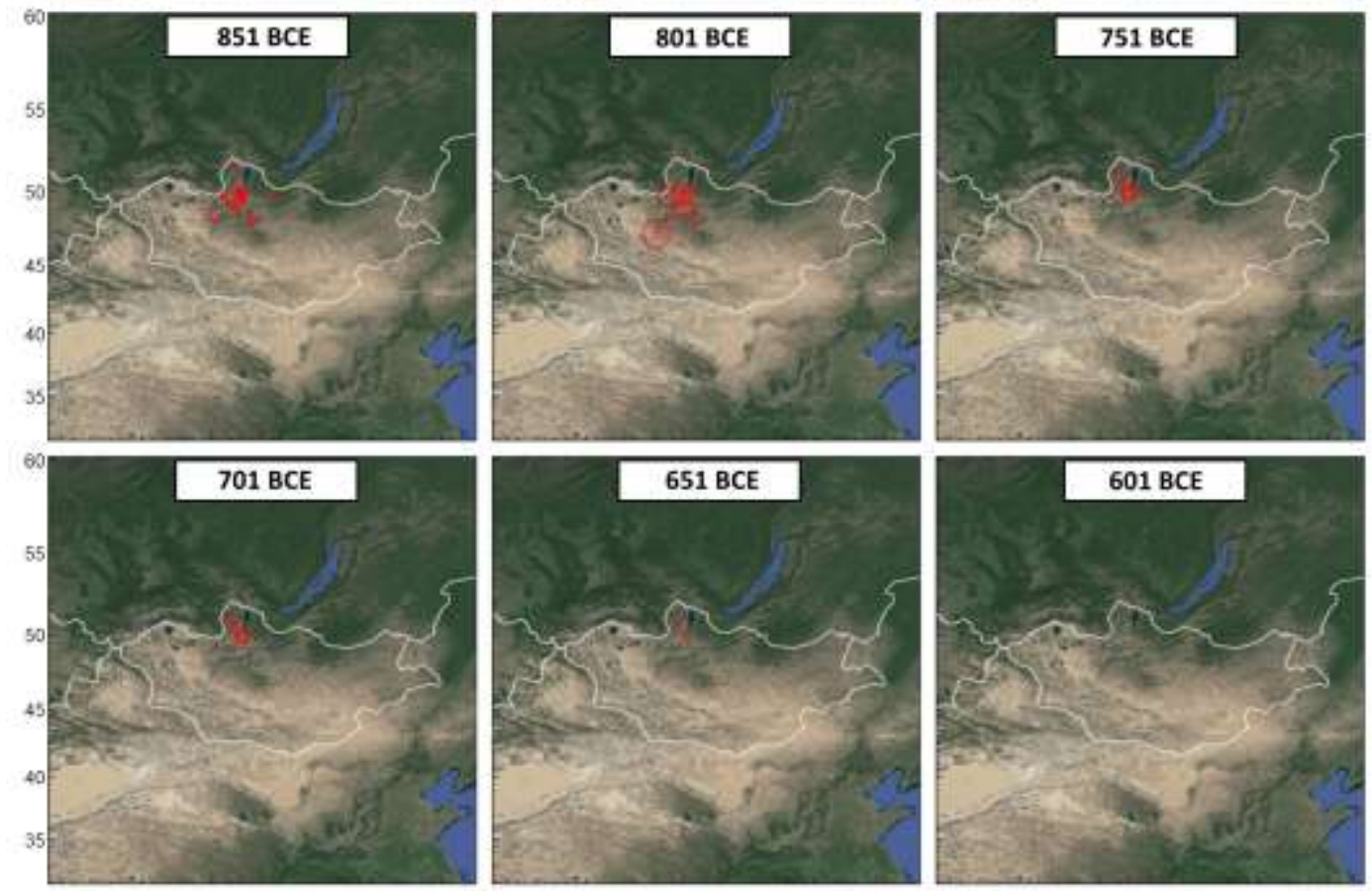

D

E 
Figure 3. Spatial distribution of DSK horse radiocarbon dates with available geographic provenience. For each date, the diameter of each circle corresponds to the percentage of the date's posterior probability distribution that falls within the time-slice.

\section{Discussion}

Model results point to a rapid adoption of horse ritual across the Mongolian steppe circa 1200 $B C E$, and provide several important clues to the origins of nomadic societies in East Asia. The modeled start date for DSK horse ritual is remarkably consistent with estimates for the arrival of domestic horses in China, which archaeologists typically place somewhere between ca. 1250-1150 BCE (e.g. Kelekna 2009; Linduff 2003; Wu 2013, see Figure 4). In recent years, several researchers have advanced the idea that horses and 'chariots' or wheeled vehicles came to the region via the Mongolian steppe (e.g. Honeychurch 2015; Shelach 2009). Our results are consistent with this hypothesis, and suggest that the first appearance of horses and wheeled vehicles in China may have been linked to the expansion of horse ritual and the erection of deer stones in Mongolia.

The suggestion that khirigsuur construction may precede the earliest horse features by nearly a century has important implications for the origins of horseback riding in eastern Eurasia. Turbat (2017) has noted that many of the oldest dates on features reported in the literature as khirigsuurs come from mounds without any satellite features - mounds that might be more accurately characterized as slope burials (or to use his term, Sagsai). He interprets the earlier date for the oldest features, along with their continued construction throughout the DSK period, as evidence of ancestral connection to the DSK complex. Our oldest "khirigsuur" date also derives from a mound lacking satellite features, and consequently our results may be consistent with this interpretation. If correct, this would imply that new domestic horse ritual practices were incorporated into an existing culture, rather than emerging through the immigration of a new people into the region.

One key interpretive concern is that the earliest observations driving this pattern are derived from human bone (Table S1). A significant dietary contribution from freshwater resources can produce an offset in radiocarbon measurements, and is known to bias human remains to yield an older date on the order of several centuries (Phillipsen 2013). Since many of the khirigsuur (or slope burial) human specimens in our sample derive from lake-rich areas of northern Mongolia - Khuvsgul and Uvs provinces, such reservoir effects are a valid methodological concern. Without dateable non-human organic material from these putatively early features, resolving this issue may require more careful consideration of modern and archaeological isotope signatures beyond the scope of this paper. In any case, the rapid, widespread appearance of DSK horse burials across the Eastern Steppe, without a recognizable spatial gradient, seems inconsistent with a gradual diffusion of domestic horses into the region.

Many cultures have used horses, and conducted equine funerary ritual, without these processes leaving an archaeological signature (e.g., Mitchell 2015:110). Subsequently, the spread of horse burials during the DSK period could simply indicate a resurgence in ritual practice, rather than a meaningful shift in horse use. However, a proliferation of associated ritual activity often reflects increased investment in managing a domestic resource (Zeder 2016:334). Moreover, the similarity between 
modeled dates for deer stones and horse ritual features suggests that this period also witnessed important social transformations, which are often linked with the adoption of horse transport (Anthony et al. 1991).

The appearance of horses in ritual features ca. 1200 BCE is also mirrored in another late Bronze Age culture found in southern and eastern regions of Mongolia, known variously as the Ulaanzuukh, Tevsh, Shape Burial, or Shorgooljin Bulsh ("Ant-shape" burial) culture. Burials of this culture began as early as the middle Bronze Age (1739-1528 cal. BCE, 95\% probability, Tumen et al. 2012). Ulaanzuukh features often contain domestic fauna, and the people who erected them appear to have lived a pastoral lifestyle (Honeychurch 2015:122-3). However, the small handful of directly dated features containing horse remains all yielded radiocarbon dates of ca. $3000{ }^{14} \mathrm{C}$ yr BP or later (Table 2), precisely coeval with the earliest horse dates from deer stones and khirigsuurs. The consistency of this pattern across two different LBA cultures is difficult to reconcile with endogenous changes in horse ritual practices. Instead, it suggests a major, pan-cultural change in domestic horse use at this time, such as the introduction of horses as a livestock animal or the development of horseback riding.

\section{Understanding DSK horse transport}

Distinguishing horseback riding from other kinds of transport in the archaeological record (carts or wheeled vehicles) in the archaeological record is a steep challenge. Several images depicting horses hitched to wheeled vehicles were directly carved into deer stones themselves (Nyambat and Odbaatar 2010:63-64), and the modeled start date for DSK horse use is coeval with the first appearance of horses and 'chariots' in China (Figure 4). These considerations make it seem exceedingly likely that DSK people used horses as draft animals, and make the initial introduction of both horses and chariots an attractive explanation for the observed patterns in horse ritual.

However, several lines of evidence suggest that the proliferation of DSK horse burials was linked to the adoption of mounted riding. For example, osteological deformation to the nasal bones and premaxillae of horses recovered from deer stones and khirigsuur ritual features indicate that many were bridled and heavily exerted (Taylor et al. 2015; Taylor et al. 2016), with adult male horses buried in special locations on the eastern edge of DSK monuments (Taylor 2016). Although these observations alone do little to distinguish riding from other forms of horse transport, asymmetry in some cranial features linked to human activity observed in some DSK horses might be explained by left-handed reining during horseback riding (Taylor and Tuvshinjargal in press). At least one preliminary report identified human skeletal pathologies linked with horseback riding in human burials from khirigsuurs (Frohlich et al. 2009:107). Finally, our model indicates that DSK horse ritual persisted in northern Mongolia until at least $800 \mathrm{BCE}$, coeval with the burials at Arzhan (Figure 3). At this site, archaeologists discovered bronze snaffle bits, cheekpieces, and other evidence for mounted riding (Jacobson-Tepfer 2015:245), along with a portion of an inhumed deer stone (Rolle 1980:44). The Arzhan discovery highlights cultural links between DSK culture and first millennium BCE equestrian peoples in Tuva and south Siberia (Hanks 2012). Most importantly, it suggests that for at least the latest portion of the DSK period, horseback riding was actively practiced in adjoining areas of northeast Asia by a culture with ties to the DSK complex. In summary, while it appears that DSK people had and used horses to pull wheeled vehicles, contextual data from equine and human skeletal remains, as well as links to early Iron Age 
cultures associated with mounted riding strongly suggest that the proliferation of DSK horse ritual was linked to the innovation or local adoption of mounted riding.

\section{Model results in paleoenvironmental context}

The modeled date of ca. 1200 BCE suggested by our Bayesian analysis provides compelling evidence against a causative role for drought or environmental scarcity in the adoption of horse riding or the expansion of East Asian mobile pastoral groups. Regional paleoclimate data indicates that DSK horse ritual began after a prolonged period of regional drought in the steppes of northern and central Mongolia, and following the onset of an apparently cooler and wetter climate regime. A well-dated lake core at Gun Nuur in Selenge, northern Mongolia suggests shallow lake levels caused by dry conditions at between 3900-3500 BP, with an onset of wetter conditions at around 1500 BCE (Feng et al. 2013:17268). Pollen records retrieved from Khuvsgul lake in northern Mongolia show a proliferation of dry species between ca. 5,300 and 4000 YBP, with this apparent drought ending by ca. 3,471 cal. BP or ca. 1500 BCE (Propokenko et al. 2007:10). A dated sediment column from the area of Kharkhorum, also in Arkhangai, shows an increase in fluvial deposition at ca. 3000 YBP(Lehmkuhl et al 2011:41-42). Considering pollen, diatom, and sediment data from lake Ugii Nuur in in central Mongolia alongside other published paleoclimate data, Wang et al. (2011:82) suggest argue that a mid-Holocene drought period characterized the northern Mongolian plateau between ca. $5120{ }^{14} \mathrm{C}$ YBP (ca. $3950 \mathrm{BCE}$ ) and $3080{ }^{14} \mathrm{C}$ YBP at (ca. 1340 BCE, Figure 4). If the DSK complex represents the emergence of highly mobile horse pastoralism in Mongolia, this chronology casts serious doubt on causative links between drought and the adoption of nomadic herding lifeways (e.g. Khazanov 1984:94), instead suggesting that the spread of horse herding and transport in Mongolia took place in the context of climate amelioration.

Table 2. Radiocarbon dates from Ulaanzuukh/Tevsh/Shorgooljin Bulsh features containing horse remains.

\begin{tabular}{|c|c|c|c|c|c|c|}
\hline ID & $\begin{array}{c}{ }^{14} \text { C Date } \\
\text { Ref }\end{array}$ & $\begin{array}{l}{ }^{14} \mathrm{C} \\
\text { Date } \\
\text { (BP) }\end{array}$ & $\begin{array}{l}\text { Uncertainty } \\
(\sigma)\end{array}$ & Material & Monument type & Reference \\
\hline $\begin{array}{l}\text { Sukhbaatar aimag, } \\
\text { Dornod Mongol } \\
\text { Ulaanzuukh Burial C }\end{array}$ & $\begin{array}{l}\text { IAAA- } \\
103370\end{array}$ & 3054 & 29 & $\begin{array}{l}\text { Human Bone } \\
\text { (assoc. w/ } \\
\text { horse) }\end{array}$ & Ulaanzuukh/Shorgooljin & Tumen et al. 2012 \\
\hline $\begin{array}{l}\text { Sukhbaatar aimag, } \\
\text { Dornod Mongol } \\
\text { Ulaanzuukh Burial } 3\end{array}$ & $\begin{array}{l}\text { IAAA- } \\
103373\end{array}$ & 3006 & 30 & $\begin{array}{l}\text { Human Bone } \\
\text { (assoc. w/ } \\
\text { horse) }\end{array}$ & Ulaanzuukh/Shorgooljin & Tumen et al. 2012 \\
\hline $\begin{array}{l}\text { Dundgovi aimag, BGC, } \\
\text { Baga Mongol EX } 07.23\end{array}$ & $\begin{array}{l}\text { Not } \\
\text { reported }\end{array}$ & 2990 & 40 & $\begin{array}{l}\text { Human Bone } \\
\text { (assoc. w/ } \\
\text { horse) }\end{array}$ & Ulaanzuukh/Shorgooljin & Nelson et al. 2009 \\
\hline $\begin{array}{l}\text { Bayankhongor aimag, } \\
\text { Ulziit sum, Bulgan Uul }\end{array}$ & AA108307 & 2482 & 27 & Horse tooth & Ulaanzuukh/Shorgooljin & This study \\
\hline
\end{tabular}

In several recent works, scholars have posited a relationship between wetter climate intervals, grassland productivity, and the expansion of nomadic polities (Kradin 2015:45-46; Putnam et al. 2016; Pederson et al. 2014). The short Mongolian summer features mild temperatures, and is wet enough to sustain relatively productive grasslands (Goulden et al. 2011:91). However, due to the extreme 
seasonality of precipitation, plant cover regenerates slowly and is particularly susceptible to damage from grazing. Consideration of these factors raises the possibility that ecological decision-making played an important role in the origins of East Asian mobile pastoralism. The increased herding efficiency provided by horse transport would have enabled mobile pastoralists to tend more groups of animals across a larger territory, reducing the labor necessary to control large groups of animals or move them to new pastures.

In the context of improving climate and its accompanying opportunities for grazing, innovations in horse transport- whether through riding skill, better horse equipment, or by breeding horses with a more manageable temperament - would have enabled herders to capitalize on new ecological opportunities. Given the increasing returns to scale associated with livestock herding (e.g. BorgerhoffMulder 2010), the increased efficiency provided by horse riding might have favored rapid territorial expansion in DSK society. In this case, changes in horse transport among early Mongolian nomads might have prompted interaction between new groups of people, and facilitated the spread of horses and horse carts to China ca. 1200 BCE.

Connectivity, communication, and trade

The innovation or adoption of horseback riding may have had a dramatic effect on the social, economic, and ecological landscape of eastern Eurasia. In recent years, archaeologists have become increasingly cognizant of the ways in which nomadic networks shaped patterns of trade and interaction across the Eurasian interior (e.g. Frachetti 2017). Early trans-Eurasian trade networks saw an intensification of exchange and an expansion of the scale of social interaction during the early first millennium BCE (Christian 2000:82-83; Frachetti 2008:141). In addition to functioning as a desirable trade good themselves, horse transport would also have positioned DSK nomads to capitalize on trade through the continental interior like never before. The new trade networks facilitated by horse transport and the expansion of mobile pastoralism in Mongolia may have prompted the exchange of metals, ideas, beliefs, artifact styles, and domesticates across eastern Eurasia (Honeychurch 2015:69).

In a changing global system brought about by increasing connectivity, those groups able to successfully leverage their advantages, such as geographic location, ecologically favorable circumstances, or technology, often benefit greatly at the expense of those who are not (e.g. HelanderRenvall 2008; Mann 2011). In later centuries, horse cavalry underwrote pastoral military successes, laying the foundation for the spread of horse cultures across most of the Eurasian interior and the formation of nomadic empires (Drews 2004:73). It appears likely that horse transport, combined with favorable ecological circumstances, also prompted the rapid expansion of DSK culture at the end of the second millennium BCE.

In addition to establishing patterns of connectivity and interaction, the changes in horse use effected by DSK people thus appear to have had a lasting impact on both religious practices and social landscape in the Mongolian steppe (Fitzhugh 2009b: 406). Horses influenced the kinds of symbols used in ritual practices (Bayarsaikhan 2017), and the location of sacred places (Houle 2010:192; Rogers 2012:211). For example, khirigsuur clusters appear to have been located along important travel corridors, and their spacing may reflect network sizes defined by horseback travel (Seitsonen et al. 
2014). DSK ritual sites would continue to be reused as important burial locations for centuries to come, serving as important foci in the ritual landscape (Clark 2014:152).

Results from the Bayesian analysis of archaeological radiocarbon dates indicate that late Bronze Age people rapidly adopted horse ritual practices across much of the Mongolian steppe circa $1200 \mathrm{BCE}$, concurrent with the first appearance of horses and wheeled vehicles in China, and after the cessation of a prolonged drought across much of Mongolia. Although it remains unclear whether this process was linked to the initial introduction of domestic horses or the adoption of horseback riding, contextual evidence links the spread of horse ritual practices with the construction of deer stone monuments, and a major change in horse use during the late Bronze Age. The proposed chronology is inconsistent with a link between drought and increased mobility or nomadic lifeways, and invites further study into the ecological context of early horseback riding.

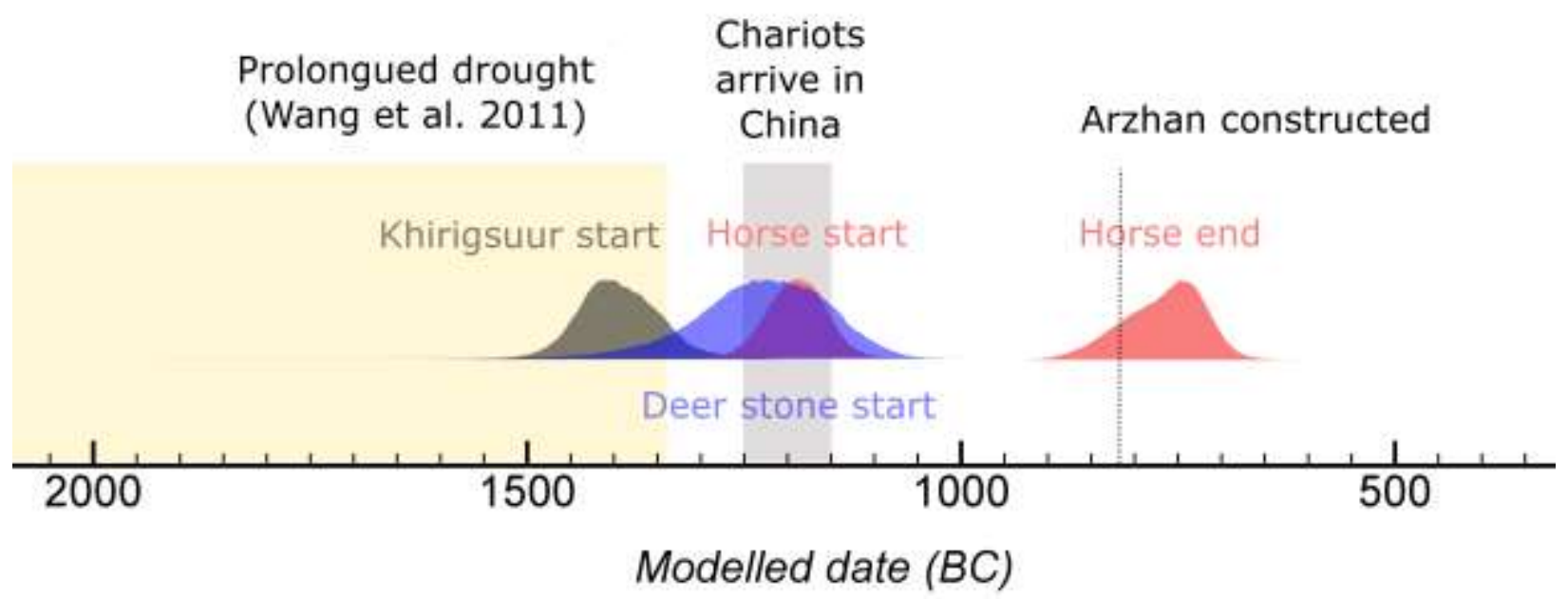

Figure 4. Modeled cultural phase start dates, as compared to large-scale climate data from Wang et al. 2011 (yellow), and important regional events in horse use.

\section{Acknowledgments}

This research was funded by National Science Foundation Doctoral Dissertation Improvement Grant \#15222024, Fulbright U.S. Student Program Award \#34154234, and National Geographic Young Explorer's Grant \#9713-15, with support from the University of New Mexico. Special thanks to Dr. Michael Dee and Dr. Emily Lena Jones for providing feedback on early versions of this manuscript, to two anonymous reviewers for their detailed and constructive feedback, and to Dr. Greg Hodgins and his staff at the Accelerator Mass Spectrometry Lab at the University of Arizona for providing training and material support for radiocarbon analysis.

\section{References}

Anthony D, Brown D (2011) The Secondary Products Revolution, Horse-Riding, and Mounted Warfare. J World Prehist 24: 131-160 
Anthony D, Telgin D, Brown D (1991). The Origin of Horseback Riding. Scientific American 265:94-99.

Anthony D, Brown D, George C (2006). Early horseback riding and warfare: the importance of the magpie around the neck, in Horses and humans: the evolution of the equine-human relationship, edited by S. Olsen, S. Grant, A. Choyke, and L. Bartosiewicz. Archaeopress, Oxford.

Allard F, Erdenebaatar D (2005). Khirigsuurs, ritual, and mobility in the Bronze Age of Mongolia. Antiquity 79:547-563

Allard F, Erdenebaatar D, Olsen S, Cavalla A, Maggiore E (2007). Ritual horses in Bronze Ageand present day Mongolia: some preliminary observations from Khanuy Valley, in Social orders and social landscapes (Proceedings of the 2005 University of Chicago Conference on Eurasian Archaeology), edited by L. Popova, C.Hartley \& A. Smith. Cambridge Scholars, Newcastle-upon-Tyne.

Amartuvshin Ch, Jargalan B (2010). Khurel Zevsgiin Uyeiin Bulshnii Sudalgaa. Dundgovi Aimagt Hiisen Arheologiin Sudalgaa: Baga Gazyriin Chuluu. Mongolian Academy of Sciences, Ulaanbaatar.

Argent G (2011). At Home With the Good Horses: Relationality, Roles, Identity and Ideology in Iron Age Inner Asia. Ph.D. Dissertation, University of Leicester, Leicester, UK.

Bayarsaikhan J

(2016). Deer Stones of Northern Mongolia. Ph.D. Dissertation, National University of Mongolia, Ulaanbaatar, Mongolia.

(2017) From Deer to Horse: Symbolism on Mongolian Ritual Stone Stelae. Paper presented at Monuments and Pastoral Regimes - Archaeology of Inner Asia from the Neolithic to the Early Iron Age, University of Bonn, Bonn, March 2017.

Bayliss A

(2009). Rolling out revolution: using radiocarbon dating in archaeology. Radiocarbon 51(1):123-147

(2015). Quality in Bayesian chronological models in archaeology. World Archaeology 47(4):677-700

Beardsley RK (1953). Hypotheses on Inner Asian Pastoral Nomadism and Its Culture Area. Memoirs of the Society for American Archaeology 9 (Asia and North America: Transpacific Contacts):24-28.

Borgerhoff-Mulder M, Fazzio I, Irons W, McElreath R, Bowles S, Bell A, Hertz T, Hazzah L (2010). Pastoralism and Wealth Inequality: Revisiting an old question. Current Anthropology 51(1):35-48

Broderick LG., Houle J-L, Seitsonen O, Bayarsaikhan J (2014). The Mystery of the Missing Caprines: Stone Circles at the Great Khirigsuur, Khanuy Valley. Arkheologiin Suudal XXXIV F13. Mongolian Academy of Sciences, Ulaanbaatar.

Bronk Ramsey C

(1998) Probability and Dating. Radiocarbon 40(1): 461-474

(2009). Bayesian Analysis of Radiocarbon Dates. Radiocarbon 51(1):337-360.

Bronk Ramsey C, Lee S (2013). Recent and planned developments of the program OXCAL. Radiocarbon 55(2-3):720-730. 
Christian D (2000) Silk roads or steppe roads? The silk roads in world history. Journal of World History 11(1): 1-26. http:// dx.doi.org/10.1353/jwh.2000.0004

Clark J (2014). Modeling Late Prehistoric and Early Pastoral Adaptations in Northern Mongolia's Darkhad Depression. Ph.D. Dissertation, University of Pittsburgh.

Dee M, Wengrow D, Shortland A, Stevenson A, Brock F, Link LG, Bronk Ramsey C (2013). An absolute chronology for early Egypt using Bayesian statistical modeling. Proceedings of the Royal Society $A$ 469(2159).

Erdene-Ochir N, Khodyakov YS (2016). Mongoliin Ertnii Nudelchdiin Zer Zevseg. New Research on Mongolian Archaeology Series, Vol. 2. Institute of History and Archaeology, Mongolian Academy of Sciences, Ulaanbaatar.

Eregzen G (2016). Ancient Funeral Monuments of Mongolia. Mongolian National Academy of Sciences, Ulaanbaatar.

Feng ZD, Ma YZ, Zhang HC, Narantsetseg Ts, Zhang XS (2013). Holocene climate variations retrieved from Gun Nuur lake-sediment core in the northern Mongolian Plateau. The Holocene 23(12):17211730

Fitzhugh W

(2004). The Hovsgol Deer Stone Project: 2003 Field Report. Smithsonian Institution, Washington, D.C.

(2009). The Mongolian Deer Stone-Khirigsuur Complex: Dating and Organization of a Late Bronze Age Menagerie. In Current Archaeological Research in Mongolia: Papers from the $1^{\text {st }}$ International Conference on Archaeological Research in Mongolia held in Ulaanbaatar, August $19^{\text {th }}-23^{\text {rd }}, 2007$, edited by J. Bemmann, H. Parzinger, E. Pohl, and D. Tseveendorj, pp. 183-199. University of Bonn, Bonn.

Fitzhugh W, Bayarsaikhan J (2009). American-Mongolian Deer Stone Project: Field Report 2009. Smithsonian Institution, Washington, D.C.

Fitzhugh W, Kortum R (2012). Rock Art and Archaeology: Investigating Ritual Landscape in the Mongolian Altai Field Report 2011. Smithsonian, Washington, D.C.

Fitzhugh W, Kortum R, Bayarsaikhan J (2013). Rock Art and Archaeology: Investigating Ritual Landscape in the Mongolian Altai Field Report 2012. Smithsonian, Washington, D.C.

Frachetti M (2008) Pastoralist Landscapes and Social Interaction in Bronze Age Eurasia. University of California Press, Berkeley.

Frachetti M, Smith CE, Traub C, Williams T (2017) Nomadic ecology shaped the highland geography of Asia's Silk Roads. Nature 543:193-198.

Frohlich B et al. (2009). Bronze Age Burial Mounds in the Khovsgol Aimag, Mongolia. In Current Archaeological Research in Mongolia: Papers from the $1^{\text {st }}$ International Conference on Archaeological Research in Mongolia held in Ulaanbaatar, August $19^{\text {th }}-23^{\text {rd }}, 2007$, edited by J. Bemmann, H. Parzinger, E. Pohl, and D. Tseveendorj, pp. 99-115. University of Bonn, Bonn. 
Gantulga J, Yeruul-Erdene Ch, Magail J (2016). Khoid Tamirin Bugan Khushuu. New Research on Mongolian Archaeology Series, Vol. 3. Institute of History and Archaeology, Mongolian Academy of Sciences, Ulaanbaatar.

Goulden C, Nandintsetseg B, Ariuntsetseg L (2011). The Geology, Climate, and Ecology of Mongolia. In Mapping Mongolia: Situating Mongolia in the World from Geologic Time to Present, edited by P. Sabloff. University of Pennsylvania Museum of Archaeology and Anthropology, Philadelphia.

Hayashi T (2013). The Beginning and the Maturity of Nomadic Powers in the Eurasian Steppes: Growing and Downsizing of Elite Tumuli. Ancient Civilizations from Scythia to Siberia 19: 105-141 Honeychurch W (2015). Inner Asia and the Spatial Politics of Empire: Archaeology, Mobility, and Culture Contact. Springer, New York.

Helander-Renvall E (2008). Logical Adaptation to Modern Technology - Snowmobile Revolution in Sápmi. In The Borderless North: The fourth Northern Research Forum, edited by L. Heininen and K. Laine. Thule Institute, University of Oulu, Oulu, Finland. Available online at https://www.rha.is/nrf/open-assemblies/oulu-lule-2006/proceedings

Houle J-L

(2010). Emergent Complexity on the Mongolian Steppe: Mobility, Territoriality, and the Development of Early Nomadic Polities. Doctoral Dissertation, University of Pittsburgh, Pittsburgh

(2016). Western Mongolia Archaeology Report 2015, University of Western Kentucky, Bowling Green, KY.

(2017). Long Term Occupation and Seasonal Mobility in Mongolia: A Comparative Study of Two Mobile Pastoralist Communities. In Fitful Histories and Unruly Publics: Rethinking Temporality and Community in Eurasian Archaeology, edited by K. Weber, E. Hite, L. Khatchadourian, and A. Smith. Brill, Leiden.

Jacobson-Tepfer E

(2012).The Image of the Wheeled Vehicle in the Mongolian Altai: Instability and Ambiguity. The Silk Road 10:1-28.

(2015). The Hunter, the Stag, and the Mother of Animals. Oxford University Press, London.

Janz L (2012). The Chronology of Post-Glacial Settlement in the Gobi Desert and the Neolithization of Arid Mongolia and China. Ph.D. Dissertation, University of Arizona

Janz L, Odsuren D, Bukhchuluun D (2017). Transitions in Palaeoecology and Technology: Hunter Gatherers and Early Herders in the Gobi Desert. Journal of World Prehistory (2017), DOI 10.1007/s10963-016-9100-5

Kelekna P (2009). The Horse in Human History. Cambridge University Press, London Khazanov A (1984). Nomads and the Outside World. University of Wisconsin Press, Madison, WI. 
Kradin N (2015). The Ecology of Inner Asian Pastoral Nomadism. In The Ecology of Pastoralism, edited by P. Nick Kardulias, pp. 41-70. University Press of Colorado, Boulder.

Kovalev A, Erdenebaatar D (2010). Discovery of new cultures of the Bronze Age in Mongolia according to the data obtained by the International Central Asian Archaeological Expedition. In Current Archaeological Research in Mongolia: Papers from the $1^{\text {st }}$ International Conference on Archaeological Research in Mongolia held in Ulaanbaatar, August $19^{\text {th }}-23^{\text {rd }}, 2007$, edited by J. Bemmann, H. Parzinger, E. Pohl, and D. Tseveendorj, pp. 149-170. University of Bonn, Bonn.

Lattimore O (1940). Inner Asian Frontiers of China. Beacon Press, Boston.

Lee S, Bronk Ramsey C (2012). Development and application of the trapezoidal model for archaeological chronologies. Radiocarbon 54:107-22.

Levine $M(1998)$. Eating horses: the evolutionary significance of hippophagy. Antiquity 72:90-100

Linduff K (2003). A Walk on the Wild Side: Late Shang Appropriation of Horses in China. In Prehistoric steppe adaptation and the horse, edited by M.Levine, C. Renfrew, and K. Boyle. McDonald Institute for Archaeological Research, Oxford.

Littleton J et al. (2012). Taphonomic analysis of Bronze Age burials in Mongolian khirigsuurs. Journal of Archaeological Science 39: 3361-3370

Mann C (2011). 1493: Uncovering the New World Columbus Created. Vintage Books, New York.

Mitchell P (2015). Horse Nations: The Worldwide Impact of the Horse on Indigenous Societies Post1492. Oxford University Press, London.

Müller-Wille L, Pelto P (1971). Technological change and ist impact in Arctic regions: Lapps introduce snowmobiles into reindeer herding. Polarforschung 41: 142-8

Nyambat M, Odbaatar Ts (2010) Zuunkhangai Sumiin Nutgaas Shineer Oldson Bugan Khushuu. Nomadic Heritage Studies 10(4), 57-66

Olsen S (2006). Early horse domestication: weighing the evidence. In: Horses and Humans: the Evolution of Human-Equine Relationships, edited by S. Olsen, S. Grant, A. Choyke, and L.

Bartosiewicz. Archaeopress, Oxford.

Outram A. et al. (2009). The Earliest Horse Harnessing and Milking. Science 323:1332-1335

Pederson N, Hessl A, Baatarbileg N, Anchukaitis K, Di Cosmo N (2014). Pluvials, droughts, the Mongol Empire, and modern Mongolia. Proceedings of the National Academy of Sciences 111(12): 43754379.

Phillipsen B (2013). The freshwater reservoir effect in radiocarbon dating. Heritage Science 2013:124 http://www.heritagesciencejournal.com/content/1/1/24

Propokenko A, Khursevich G, Bezrukova E, Kuzmin M, Boes X, Williams D, Fedenya S, Kulagina N, Letunova P, Abzaeva A (2007). Paleoenvironmental proxy records from Lake Hovsgol, Mongolia, and a synthesis of Holocene climate change in the Lake Baikal watershed. Quaternary Research 68:2-17. 
Putnam A et al. (2016). Little Ice Age wetting of interior Asian deserts and the rise of the Mongol Empire. Quaternary Science Reviews 131: 33-50.

Rogers, J. D. (2012). Inner Asian States and empires: theories and synthesis. Journal of Archaeological Research 20(3):205-256.

Rolle R (1980). The World of the Scythians. University of California Press, Berkeley.

Seitsonen O, Broderick L, Houle, J-L (2014). GIS Approaches to Past Mobility and Accessibility: An Example from the Bronze Age Khanuy Valley, Mongolia. In Past mobilities. Archaeological Approaches to Movement and Mobility, edited by J. Leary, pp.79-112. Ashgate Publishing, Farnham, UK.

Shelach G(2009). Prehistoric Societies on the Northern Frontiers of China: Archaeological Perspectives on Identity Formation and Economic Change during the First Millennium BCE. London, Equinox.

Steier P, Rom W (2000). The use of Bayesian statistics for $14 \mathrm{C}$ dates of chronologically ordered samples: a critical analysis. Radiocarbon 42(2):183-198.

Taylor W (2016). Horse demography and use in Bronze Age Mongolia, Quaternary International (2016), http://dx.doi.org/10.1016/i.quaint.2015.09.085

Taylor W, Tuvshinjargal T (In press). Horseback riding, asymmetry, and anthropogenic changes to the equine skull: evidence for mounted riding in Mongolia's Late Bronze Age. In Proceedings of the 6th Animal Paleopathology Working Group, International Council for Archaeozoology, Budapest, Hungary, edited by L. Bartosiewicz and E. Gal. Oxford, Oxbow Books.

Taylor W, Bayarsaikhan J, Tuvshinjargal T (2015). Equine Cranial Morphology and the Archaeological Identification of Riding and Chariotry in Late Bronze Age Mongolia. Antiquity 89:854-871.

Taylor W, Tuvshinjargal T, Bayarsaikhan J (2016) Reconstructing Equine Bridles in the Mongolian Bronze Age. Journal of Ethnobiology 36(3): 553-568

Tumen D, Erdene M, Khatanbaatar D, Ankhsanaa G, Tsidenova HB (2012). "Dornod Mongol-2011" Arkheologiin Kheeriin Sudalgaa. Mongolian Journal of Anthropology, Archaeology, and Ethnology 7(1):1-38.

Turbat Ts (2017). New insights into the Bronze and Early Iron Age of Mongolia. Paper presented at Monuments and Pastoral Regimes - Archaeology of Inner Asia from the Neolithic to the Early Iron Age, University of Bonn, Bonn, March 2017.

Volkov VV (2002) [1981]. Olennye kamni Mongolii (2nd edition). Ulaanbaatar: Academy of Sciences, Moscow; Nauka.

Wang W et al. (2011). A prolonged dry Mid-Holocene climate revealed by pollen and diatom records from lake Ugii Nuur, Central Mongolia. Quaternary International 229:74-83.

Wu H (2013). Chariots in Early China: Origins, Cultural Interaction, and Identity. Archaeopress, Oxford.

Wright J 
(2006)The Adoption of Pastoralism in Northeast Asia: Monumental Transformation in the Egiin Gol Valley, Mongolia. Ph.D. Dissertation, Harvard University, Cambridge.

(2012) Inequality on the surface: horses, power, and community in the Mongolian Bronze Age. In Animals and Inequality in the Ancient World, edited by B. Arbuckle and S. McCarty. University of Colorado Press, Boulder.

(2014). Landscapes of inequality? A critique of monumental hierarchy in the Mongolian Bronze Age. Asian Perspectives 51: 139-63. http://dx.doi.org/10.1353/asi.2014.0008

Yeruul-Erdene C et al (2015). Orkhonii Khundii Dekh Mongol-Germanii Khamtarsan "Barkor" Tusliin Suldalgaani Uridchilsan Ur Dun. Studia Archaeologica XXXV(14):198-216

Zeder M (2016). Domestication as a model system for niche construction theory. Evol Ecol 30:325348 


\section{Figure legends}

Figure 1. Posterior calibrated probability ranges for $14 \mathrm{C}$ dates from horse remains at deer stones and khirigsuurs. Prior distribution indicated in light gray, with median estimated indicated by $(+)$ and one and two-sigma probability ranges shown below. Distributions labeled "DSK Horse Start" and "DSK Horse End" summarize the estimated start and end boundary for horse ritual at DSK sites.

Figure 2. Modeled start and end dates for DSK horses, Khirigsuurs, and deer stones. Dashed line indicates median modeled start date for DSK horse ritual, falling within the 1-sigma range for deer stones but outside the modeled probability distribution for khirigsuurs.

Figure 3. Spatial distribution of DSK horse radiocarbon dates with available geographic provenience. For each date, the diameter of each circle corresponds to the percentage of the date's posterior probability distribution which falls within the time-slice.

Figure 4. Modeled cultural phase start dates, as compared to large-scale climate data from Wang et al. 2011 (yellow), and important regional events in horse use.

Table 1. Probability that t1 (left column) precedes t2 (top row) using OXCAL's Order function.

Table 2. Radiocarbon dates from Ulaanzuukh/Tevsh/Shorgooljin Bulsh features containing horse remains.

Table S1. Radiocarbon dates from Deer Stone and Khirigsuur archaeological sites. 
Table 1

Table 1. Probability that t1 (left column) precedes t2 (top row) using OXCAL's Order function.

Event 2

\begin{tabular}{|c|c|c|c|}
\hline & DS & KS & Horse \\
\hline DS & --- & $4.654 \%$ & $65.16 \%$ \\
\hline KS & $95.35 \%$ & --- & 99.99\% \\
\hline Horse & $34.84 \%$ & $0.001 \%$ & --- \\
\hline
\end{tabular}


Table 2. Radiocarbon dates from Ulaanzuukh/Tevsh/Shorgooljin Bulsh features containing horse remains.

\begin{tabular}{|c|c|c|c|c|c|c|}
\hline ID & $\begin{array}{c}{ }^{14} \mathrm{C} \text { Date } \\
\text { Ref }\end{array}$ & $\begin{array}{l}{ }^{14} \mathrm{C} \\
\text { Date } \\
\text { (BP) }\end{array}$ & $\begin{array}{l}\text { Uncertainty } \\
\qquad(\sigma)\end{array}$ & Material & Monument type & Reference \\
\hline $\begin{array}{l}\text { Sukhbaatar aimag, } \\
\text { Dornod Mongol } \\
\text { Ulaanzuukh Burial C }\end{array}$ & $\begin{array}{l}\text { IAAA- } \\
103370\end{array}$ & 3054 & 29 & $\begin{array}{l}\text { Human Bone } \\
\text { (assoc. w/ } \\
\text { horse) }\end{array}$ & Ulaanzuukh/Shorgooljin & Tumen et al. 2012 \\
\hline $\begin{array}{l}\text { Sukhbaatar aimag, } \\
\text { Dornod Mongol } \\
\text { Ulaanzuukh Burial } 3\end{array}$ & $\begin{array}{l}\text { IAAA- } \\
103373\end{array}$ & 3006 & 30 & $\begin{array}{l}\text { Human Bone } \\
\text { (assoc. w/ } \\
\text { horse) }\end{array}$ & Ulaanzuukh/Shorgooljin & Tumen et al. 2012 \\
\hline $\begin{array}{l}\text { Dundgovi aimag, BGC, } \\
\text { Baga Mongol EX } 07.23\end{array}$ & $\begin{array}{l}\text { Not } \\
\text { reported }\end{array}$ & 2990 & 40 & $\begin{array}{l}\text { Human Bone } \\
\text { (assoc. w/ } \\
\text { horse) }\end{array}$ & Ulaanzuukh/Shorgooljin & Nelson et al. 2009 \\
\hline $\begin{array}{l}\text { Bayankhongor aimag, } \\
\text { Ulziit sum, Bulgan Uul }\end{array}$ & AA108307 & 2482 & 27 & Horse tooth & Shorgooljin & This study \\
\hline
\end{tabular}

